\title{
Polymeric particle composites with filler saturated matrix
}

Petr Valášek, Miroslav Müller

Department of Material Science and Manufacturing Technology, Faculty of Engineering, Czech University of Life Sciences in Prague. E-mail: valasekp@tf.czu.cz.

Composites are materials which combine properties of two and more phases and create entirely new material. In case of the polymeric particle composites one phase - a matrix is represented by the polymeric material most often in a form of an epoxy resin and the second phase - a filler is composed of inorganic particles. The paper deals with the polymeric particle composites whose matrix is composed of the epoxy and polyester resin with a high concentration of a waste corundum $\left(\mathrm{Al}_{2} \mathrm{O}_{3}\right)$ particles. The paper focuses on chosen mechanical qualities of these materials: an abrasive wear resistance and an impact strength. Increased portion of the filler in the matrix predetermines these systems to considerable abrasive wear resistance. This hypothesis was confirmed by carried out experiments when the volume loss decrease of the composite systems with the matrix saturated with the particle filler reached values $0.04 \mathrm{~cm}^{3}$ whereas the volume decrease loss of the epoxy resin without the filler reached $0.56 \mathrm{~cm}^{3}$. The maximum applied saturation of the matrix with the particle filler was reached at the polyester resin when this value corresponded to 50 volume percentages.

Keywords: abrasive wear, corundum, impact strength, saturated matrix

Acknowledgement

Supported by Internal grant agency of Faculty of Engineering, Czech University of Life Sciences in Prague.

\section{Reference}

[1] EHRENSTEIN, G.W. Polymerní kompozitni materiály. Praha: Scientia, Praha, 2009, 351 p.

[2] JANČÁŘ, J. Úvod do materiálového inženýrství polymerních kompozitů. Brno: VUT, 2003, 194 p.

[3] BYUNG CHUL KIM; SANG WOOK PARK; DAI GIL LEE. Fracture toughness of the nano-particle reinforced epoxy composite. Composite Structures, 2008, p. $69-77$.

[4] DONG CHANG PARK, et al. Wear characteristics of carbon-phenolic woven composites mixed with nanoparcicles. Composite Structures, 2006, vol. 74, p. 89-98.

[5] MÜLLER, M.; VALÁŠEK, P. et al. Aplikace návarů a kompozitů v oblasti technologie pěstování a sklizně cukrové řepy. Listy cukrovarnické a řepařské, 2011, vol. 9, p. $304-307$.

[6] MÜLLER, M.; VALÁŠEK, P. Interaction of steel surface treatment by means of abrasive cloth and adhesive bond strength. Manufacturing Technology, 2010, vol. 14, p. 49 - 57.

[7] MÜLLER, M.; VALÁŠEK, P. Polymerní kompozity na bázi zpevňujících částic odpadů z procesu mechanické povrchové úpravy. Strojírenská technologie, 2010, vol. 14, p. $183-186$.

[8] SATAPATHY B.K.; BIJWE, J. Analysis of simultaneous influence of operating variables on abrasive wear of phenolic composites. Wear, 2002, vol. 253, p. 787-794.

[9] BROŽEK, M. Technicko - ekonomické hodnocení aplikace návarů u plužních čepelí. Acta univ. agric. et silvic. Mendel. Brun., 2007, LV, No. 4, p. 129 - 136.

[10] BERTHELOT, J. M.: Composite Materials - Mechanical Behavior and Structural Analysis. Berlin: Mechanical engineering series, 1998, $635 \mathrm{p}$.

[11] ČSN 62 1466: 1993. Rubber, determination of abrasion resistance using a rotating cylindrical drum device. Prague: Federal office for standard and measuring, $1993.12 \mathrm{p}$.

[12] ČSN EN ISO 868: 2003. Plastics and ebonite - Determination of indentation hardness by means of durometr (Shore hardness). Czech Standard Institution, Prague, 2003. 10 p.

[13] ČSN 64 0611: 1968. Determination of the impact resistence of rigid plastics by means of Dynstat apparatus. Czech standard institution, Prague, 1968. 5 p.

[14] MÜLLER, M.; VALÁŠEK, P. Abrasive wear effect on Polyethylene, Polyamide 6 and polymeric particle composites. Manufacturing Technology, 2012, vol. 12, p. 55 - 59. 
[15] KEJVAL, J.; MÜLLER, M.; Henc, P. Mechanické vlastnosti a „two-body“ abrazívní opotřebení polymerních částicových kompozitů. Strojírenská technologie, 2012, vol. 1,2, p. 33 - 38.

[16] NOVAK, M. (2012). Surfaces with high precision of roughness after grinding. In Manufacturing Technology, vol. 12., no. 12., UJEP, Usti nad Labem, 66-70 pp.

Paper number: M201257 